Proc. Estonian Acad. Sci. Geol., 1999, 48, 3, 140-157

\title{
BIOSTRATIGRAPHIC DATING OF PEBBLES FROM THE UPPER CAMBRIAN CONGLOMERATES IN ESTONIA
}

\author{
Kaisa MENS ${ }^{\mathrm{a}}$, Ivo PAALITS ${ }^{\mathrm{b}}$, and Ivar PUURA ${ }^{\mathrm{c}}$
}

a Institute of Geology, Tallinn Technical University, Estonia pst. 7, 10143 Tallinn, Estonia

b De Neef Baltic OÜ, Võru 2, 51010 Tartu, Estonia; deneef@kodu.ee

c Institute of Geology, University of Tartu, Vanemuise 46, 51014 Tartu, Estonia; ipuura@ut.ee

Received 21 April 1999, in revised form 28 May 1999

\begin{abstract}
Acritarch assemblages were studied in the pebbles from basal conglomerates of the Ülgase and Kallavere formations of northern Estonia. The basal conglomerate of the Ülgase Formation in the Mäekalda section, formed during the Olenus time, contained mostly pebbles originating from the Lower Cambrian source rocks, most likely from the Tiskre, Soela, or Vaki formations. The basal conglomerate of the Kallavere Formation in the Pakri Peninsula section, formed slightly before or during the Cordylodus proavus time, contained pebbles with Lower and Upper Cambrian acritarch assemblages. The Upper Cambrian source rocks originate likely from the Ülgase or the Tsitre Formation. Both conglomerates contained rare pebbles with an acritarch assemblage of tentative Middle Cambrian age. The source rock of these pebbles remains disputable, with the Ruhnu and Paala formations, or a missing, completely denudated and reworked part of the Middle Cambrian sequence as hypothetical options.
\end{abstract}

Key words: Cambrian, sedimentary conglomerate, acritarchs, Estonia.

\section{INTRODUCTION}

The Cambrian succession of Baltoscandia, represented by siliciclastic deposits and alum shales (Mens et al., 1990), is rather incomplete, with numerous gaps of different duration (Mens \& Pirrus, 1987). In Estonia, the exposure area of the Cambrian is limited to the coastal cliff and river valleys in the northernmost part of the mainland. In all Cambrian outcrops, a major hiatus between the Lower and the Upper Cambrian can be observed: along the outcrop belt extending from the 
Pakri Peninsula to the Narva River, the Lower Cambrian Tiskre Formation is overlain by different Upper Cambrian formations (Kaljo et al., 1986; Mens \& Pirrus, 1997). It is expected that the pebbles in conglomerates, occasionally occurring at the base of the Upper Cambrian strata, may contain new information relevant to interpreting the geological history of the region.

In our previous pilot study we have shown that acritarch assemblages can be used for establishing the biostratigraphic age and provenance of the pebbles (Mens et al., 1997). The present paper deals with the pebbles from two distinct conglomerates in two sections: (1) the older conglomerate at the base of the Ülgase Formation in the Mäekalda section and (2) the younger conglomerate at the base of the Kallavere Formation in the Pakri Peninsula section. These sections have earlier been described in Mens et al. $(1989,1996,1997)$ and Nemliher \& Puura (1996). Both conglomerates overlie the Lower Cambrian Tiskre Formation. Throughout this paper, we use the term pebble for all coarse clasts in the conglomerate, regardless of their size.

\section{PREVIOUS STUDIES}

The exposure area of the Lower and Upper Cambrian rocks is limited to a narrow belt close to the seacoast in northernmost Estonia. The outcrops occur along the coastal cliff and in river valleys and nearby rare quarries. Thanks to a long tradition of research and more than three decades of the study of drill core data, the lithostratigraphy and distribution of the Cambrian rocks of Estonia are well established (Mens \& Pirrus, 1997). Modern biostratigraphic studies of the Upper Cambrian rocks, based on acritarchs, conodonts, and lingulate brachiopods, have resulted in an updated biozonation (Kaljo et al., 1986; Popov et al., 1989; Mens et al., 1990; Mens et al., 1993; Mens \& Pirrus, 1997). Acritarch assemblages from the potential source rock areas of the pebbles are also rather well known (Paalits, 1992a, 1992b, 1995; Volkova, 1982, 1990; Volkova \& Mens, 1988).

\section{GEOLOGICAL SETTING AND LOCALITIES}

The Mäekalda section (Fig. 1A) in Kadriorg Park, Tallinn, was selected for the study of the basal conglomerate of the Ülgase Formation. The section is situated in Laagna road, $150 \mathrm{~m}$ southwest of the pedestrian bridge. The $3.2 \mathrm{~m}$ thick Ülgase Formation rests on the Lower Cambrian Tiskre Formation (Mens et al., 1989). The basal part of the Ülgase Formation yields up to $2 \mathrm{~m}$ wide and up to $10 \mathrm{~cm}$ thick conglomerate lenses which contain flattened, rounded pebbles reaching $25 \mathrm{~cm}$ in diameter. The pebbles are of variable lithological composition, and the proportion of various kinds of pebbles varies in different conglomerate lenses. 


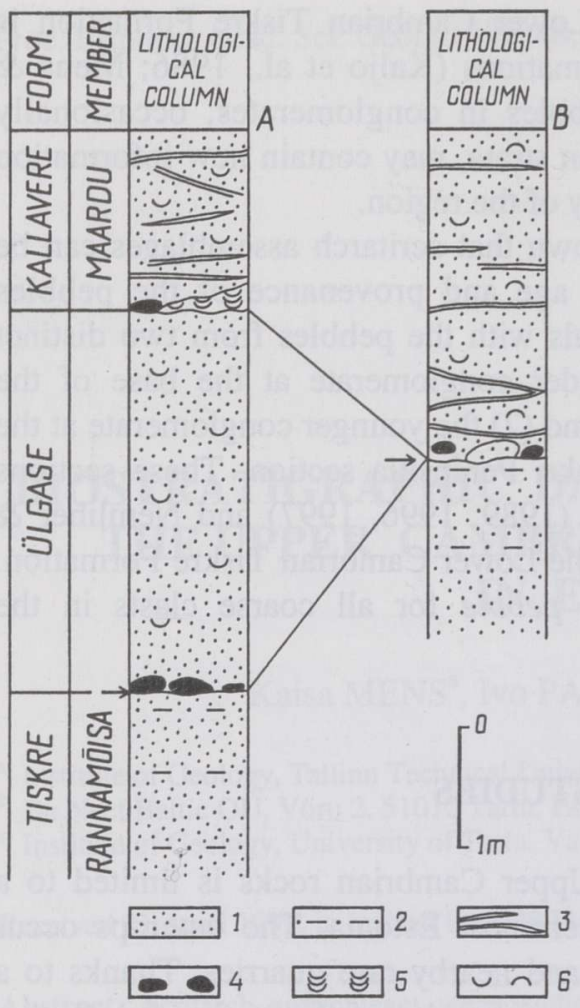

Fig. 1. Stratigraphic columns of the studied sections: A, Mäekalda (after Mens et al., 1989); B, Pakri Peninsula (after Mens et al., 1996). Arrows indicate levels where pebbles for the micropalaeontological study have been collected. 1, sandstone; 2, sandstone intercalated with claystone; 3 , interbeds of kerogenous shale; 4, conglomerate lenses; 5 , brachiopod coquina; 6 , brachiopod valves and debris.

The commonest pebbles in the sampled location consist of well-cemented, glauconite-containing, medium-grained sandstone and are surrounded by an up to $5 \mathrm{~mm}$ thick pyritized and phosphatized rim (samples Mä-96-2A, Mä-96-2B, Mä-96-2E). The grain size data and glauconite distribution pattern resemble the lithologies characteristic of the Middle Cambrian Kybartai Formation in Latvia (see Mens et al., 1990); however, no palaeontological data are available for dating.

Rather abundant are pebbles consisting of very fine-grained sandstone which yields rare scattered glauconite grains and is characterized by patchy distribution of precipitated pyrite and thin rim cement (samples Mä-96-2C, Mä-96-2H). By visual examination, these pebbles resemble lithologically the Lower Cambrian sandstones of the Tiskre Formation of the Liivi Group, and Soela or Vaki formations of the Aisčiai Group (Mens et al., 1990). The Tiskre Formation, terminating the Liivi sedimentation stage, occurs in northern and western Estonia (Fig. 2) and is represented by weakly cemented, light-coloured, massive or thickbedded quartzose, very fine-grained sandstones with interbeds of greenish-grey argillaceous rocks. Glauconite and muscovite are common. The overlying Aisčiai Group, represented by arenaceous-argillaceous strata, is known only from the core sections in a restricted area. In Estonia, it is subdivided into the Soela, Irbe (previously Irben), and Vaki formations. The Vaki Formation is considered to 


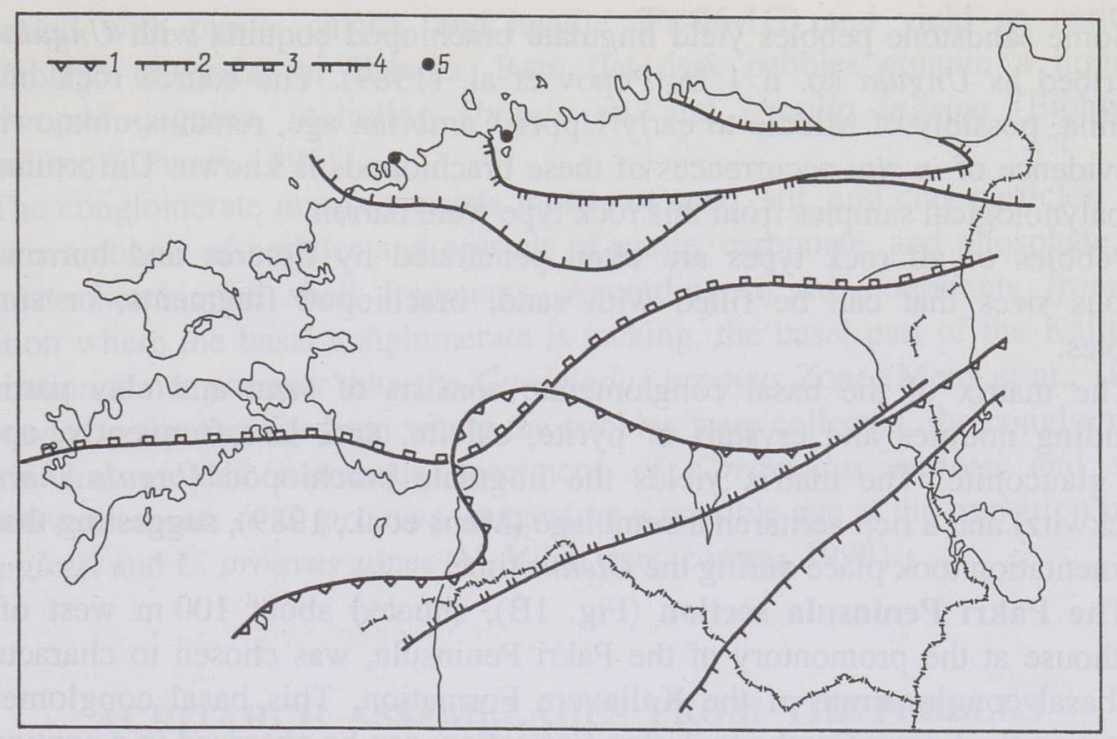

Fig. 2. Sketch-map showing location of the studied sections and the distribution areas (after Mens \& Pirrus, 1997) of potential source rocks of the pebbles reworked into two Upper Cambrian conglomerate levels in Estonia. 1, southern limit of the Liivi Group (Sõru, Lükati, Tiskre Fms.); 2, boundaries of the Aisčiai Group (Soela, Irbe, Vaki Fms.); 3, northern limit of the Middle Cambrian; 4, boundaries of the pre-Kallavere Upper Cambrian; 5, studied localities.

be a shallow water equivalent of the Soela and Irbe formations (Mens et al., 1990). The Soela Formation occurs on West Estonian islands and in the western part of the mainland. It consists of weakly cemented, light-coloured, fine-grained subarkose and quartzose sandstones. Glauconite is very common in its lower part. The overlying Irbe Formation is distributed in the same area. This formation consists of interbedded clay- and siltstones, with some brown ferriferous (goethitic) oolite interbeds. The Vaki Formation is distributed in central and southern Estonia. It consists of weakly cemented, glauconite-bearing, lightcoloured, fine-grained and/or very fine-grained sandstones with thin interbeds of greenish-grey or bleached-purplish clays. Considering the present-day distribution of the above-named stratigraphic units (Fig. 2), it appears that only the Tiskre Formation underlies directly the conglomerate lenses in the Mäekalda section, whereas the distribution area of the Aisčiai Group is located southwards. In northernmost Estonia, these deposits are lacking, most likely due to the denudation in the Middle and/or Late Cambrian.

Relatively rare are pebbles of fine-grained sandstone with muscovite and pyrite nodules on bedding planes, with no observable glauconite (Mä-96-2G). These features are not sufficient for associating these pebbles with any specific level in the Cambrian sequence of Estonia. 
Some sandstone pebbles yield lingulate brachiopod coquina with Ungula sp., described as Ungula sp. n. 1 by Popov et al. (1989). The source rock of this coquina, possibly of Middle to early Upper Cambrian age, remains unknown, as no evidence of in situ occurrences of these brachiopods is known. Unfortunately, the palynological samples from this rock type were barren.

Pebbles of all rock types are often penetrated by fissures and burrows of various sizes that can be filled with sand, brachiopod fragments, or smaller pebbles.

The matrix of the basal conglomerate consists of sand and clay particles, including nodules and crystals of pyrite, calcite, and, less frequently, apatite and glauconite. The matrix yields the lingulate brachiopod Ungula inornata (Mickwitz) and a rich acritarch assemblage (Mens et al., 1989), suggesting that the sedimentation took place during the Olenus time.

The Pakri Peninsula section (Fig. 1B), situated about $100 \mathrm{~m}$ west of the lighthouse at the promontory of the Pakri Peninsula, was chosen to characterize the basal conglomerate of the Kallavere Formation. This basal conglomerate, resting on the Lower Cambrian Tiskre Formation, can be observed in a continuous exposure extending about $1.5 \mathrm{~km}$ westward of the lighthouse. Laterally, the thickness and composition of the conglomerate vary largely, most likely due to uneven bottom topography of the Cambrian sea (Nemliher \& Puura, 1996). The conglomerate yields large boulders and poorly rounded cobbles reworked from the underlying Tiskre Formation and mostly lacking a cemented rim (Müürisepp, 1958; Nemliher \& Puura, 1996), and various kinds of pebbles.

Among the pebbles from the studied locality, two rock types are prevailing. Flat, rounded pebbles with thin rim cement are composed of well-cemented, very fine-grained, unevenly pyritized sandstones (Pa-96-1A, Pa-96-1C, Pa-96-1D, Pa-96-1F). These pebbles resemble lithologically the arenaceous rocks of the Aisčiai Group and of the underlying Tiskre Formation. The pebbles of another common type are composed of fine- to medium-grained sandstone, cemented with pyrite, carbonate, and phosphate, and sometimes yielding glauconite grains and lingulate brachiopod fragments (Pa-96-1E). The dark rim cement of apatite and pyrite varies in thickness. Lithologically, these pebbles resemble the sandstones of the Upper Cambrian Ülgase and Tsitre formations.

The Estonian Upper Cambrian succession is very condensed, interrupted by several hiatuses, and dominated by varigrained, light-coloured sand- and siltstones, less than $20 \mathrm{~m}$ in thickness. Argillaceous rocks are of limited distribution, forming grey to greenish-grey intercalations in the lower part and brownish-grey intercalations in the upper part of the succession. The lithostratigraphic subdivisions of the Upper Cambrian in tentative age order from the oldest to the youngest include the Petseri, Ülgase, and Tsitre formations and the lower part of the Kallavere Formation. The Petseri Formation occurs in southern Estonia, whereas the Ülgase and Tsitre formations are documented only in northern Estonia (Fig. 2).

Rather uncommon are thin, flat pebbles composed of very fine-grained and fine-grained sandstones, with biotite and nests of calcite. They are strongly 
cemented with pyrite, calcite, and apatite $(\mathrm{Pa}-96-1 \mathrm{G})$ and yield an acritarch assemblage untypical of Estonia. Rare flat dark pebbles contain a lingulate brachiopod coquina, including Ungula sp. and Ungula ingrica (Eichwald) (Nemliher \& Puura, 1996).

The conglomerate matrix consists mostly of sand, silt, and clay particles, with various amounts of nodules and crystals of pyrite, carbonate, and phosphate, and lingulate brachiopod shell fragments. According to the conodonts from the location where the basal conglomerate is lacking, the basal part of the Kallavere Formation is not younger than the Cordylodus proavus Zone (Mens et al., 1996). However, in the locality from where the pebbles were collected, the conglomerate matrix has yielded numerous specimens of Cordylodus andresi and some primitive elements of $C$. proavus, suggesting a possible age at the transition of the C. andresi and C. proavus zones (V. Viira, pers. comm., 1998).

\section{ACRITARCH ASSEMBLAGES FROM THE PEBBLES}

\section{Methods}

Prior to the pebble sampling in a selected locality, the upper surface of a conglomerate bed was opened in an extent of about $1.0 \times 0.5 \mathrm{~m}$. The pebbles were collected from the cleaned conglomerate surface. They were visually examined lithologically, considering grain size, mineralogical features, structure, cementation, and presence and extent of the rim cement and grouped by rock types for evaluation of their frequency. In many cases, these features allowed us to make suggestions about the source rock or to single out some potential sources.

Larger pebbles of each rock type were prepared for palynological study by cutting cube-like blocks from their interior (see Mens et al., 1997). Samples were processed using conventional palynological techniques and sieved using a $14 \mu \mathrm{m}$ nylon sieve.

\section{The basal conglomerate of the Ülgase Formation at Mäekalda}

From the seven pebbles selected for micropalaeontological study (Fig. 3), two (Mä-96-2A, Mä-96-2E) did not yield acritarchs. Very rare acritarchs found from the other two pebbles, Mä-96-2F and Mä-96-2B, were inconclusive for biostratigraphic purposes. Samples Mä-96-2C and Mä-96-2H contained a closely similar, diverse and rich assemblage, prevailed by sphaeromorphic and small acanthomorphic acritarchs (Fig. 3). Among 20 species, this assemblage includes Skiagia ciliosa (Pl. I, figs. 11, 12; Pl. II, figs. 1-6) and Heliosphaeridium dissimilare defining the corresponding Lower Cambrian acritarch zone (Moczydłowska, 1991), and other species typical of this zone (Pl. III). Based on these data, it can be concluded that the pebbles may originate from the Irbe or from the Soela 


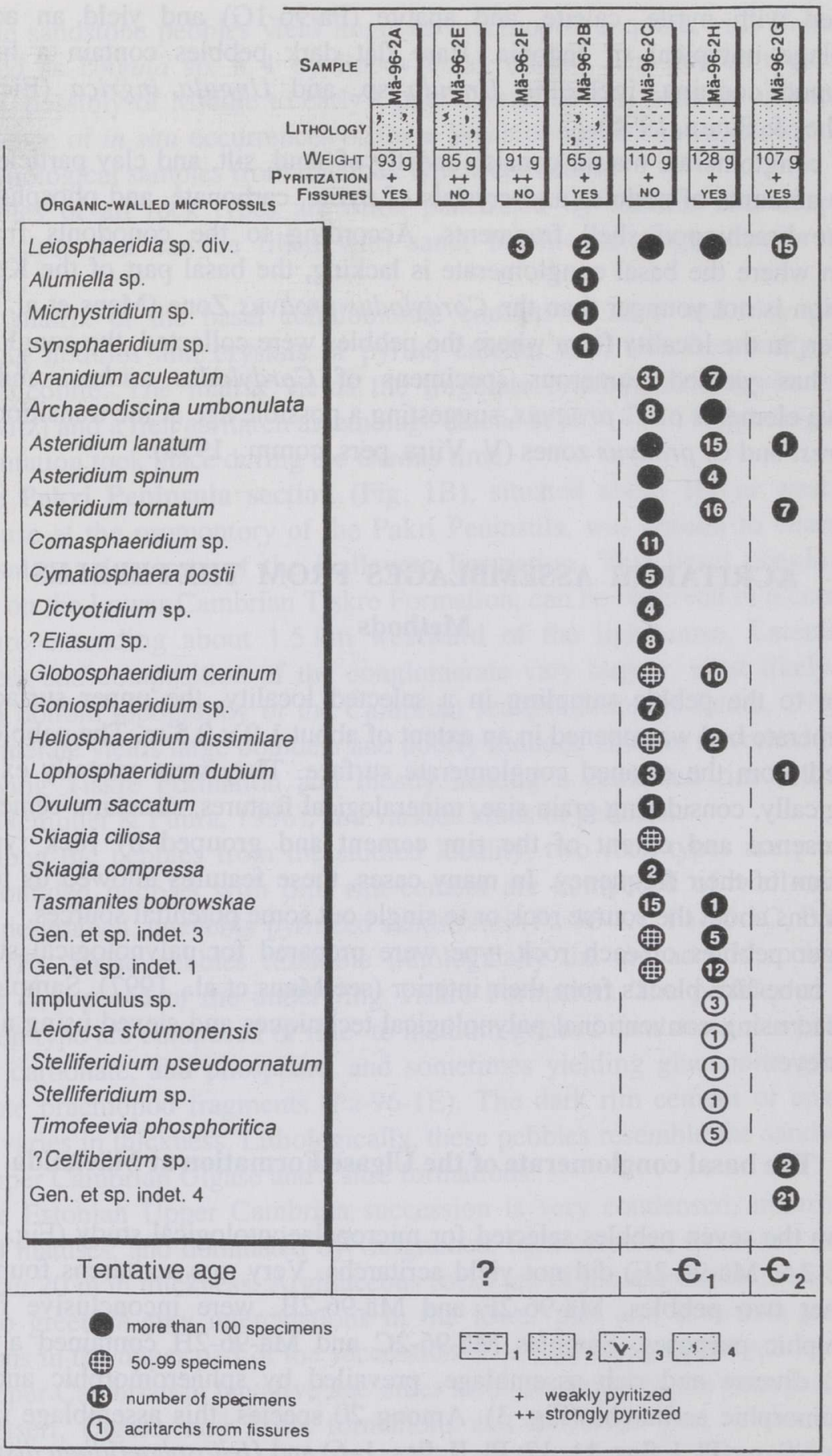

Fig. 3. Acritarch assemblages from the pebbles in the basal conglomerate of the Ülgase Formation in the Mäekalda section. 1, very fine-grained sandstone; 2, fine-grained sandstone; 3, sandstone containing brachiopods and their fragments; 4 , glauconite-containing medium-grained sandstone. 

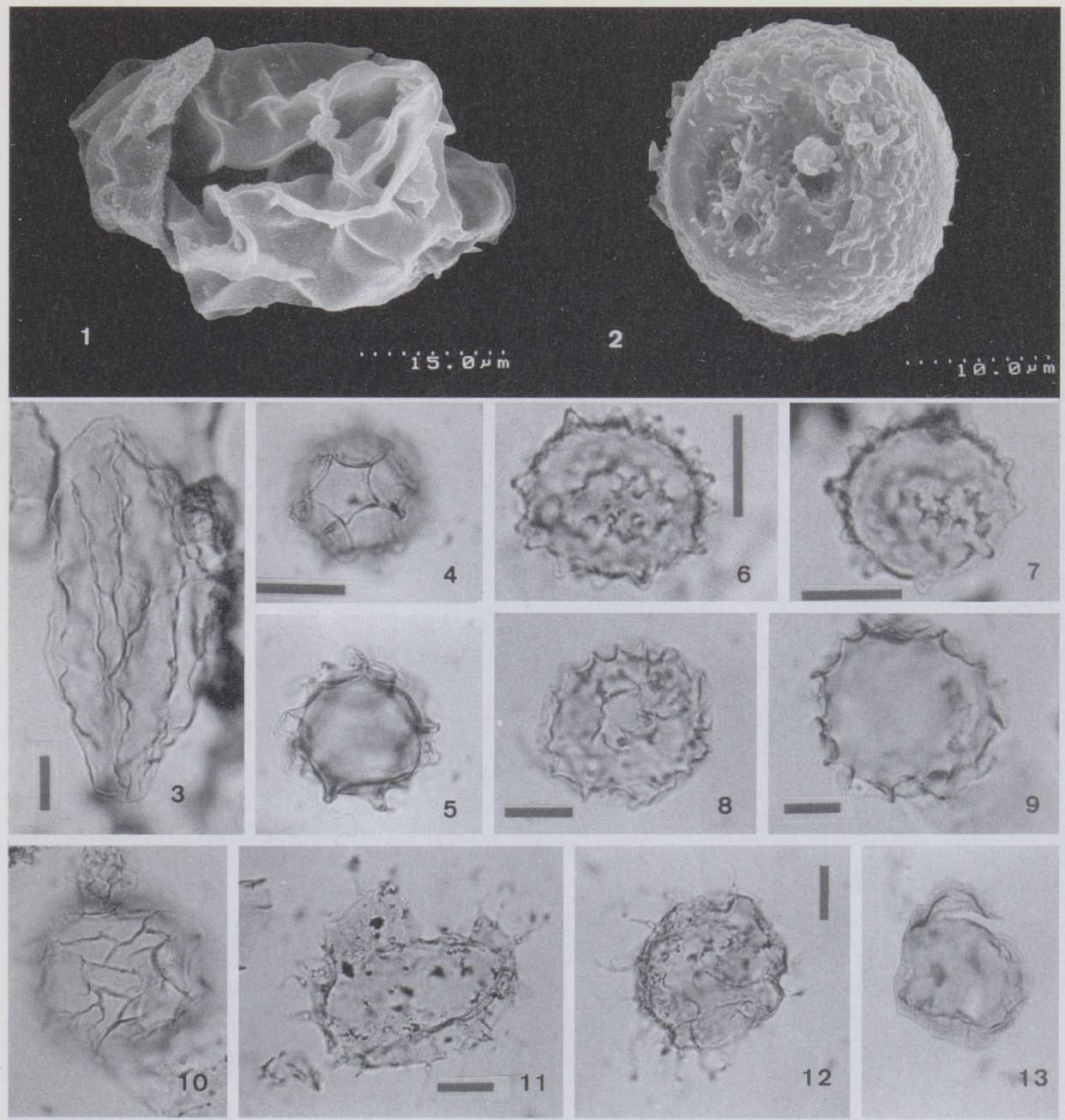

Figs. 1, 2. Acritarchs from pebble $\mathrm{Pa}-96-1 \mathrm{E}$.

Fig. 1. Pirea cf. orbiculare Volkova; sample SCAN-96 III/A9.

Fig. 2. Acritarcha gen. et sp. indet.

Figs. 3-12. Scale bar corresponds to $10 \mu \mathrm{m}$.

Fig. 3. ?Eliasum sp.; pebble Mä-96-2C, prep. 1, D29/0.

Figs. 4, 5. Timofeevia phosphoritica (Vanguestaine) Vanguestaine; pebble Pa-96-1E, prep. 2, F22/1.

Figs. 6, 7. ?Celtiberium sp.; pebble Pa-96-1G. 6, prep. 1, L26/0. 7, prep. 3, L29/1.

Figs. 8-10. Dictyotidium sp., pebble Pa-96-1G, prep. 1, G11/3.

Figs. 11, 12. Skiagia ciliosa (Volkova) Downie; pebble Mä-96-2C. 11, prep 1, P14/0. 12, prep. 1, $\mathrm{J} 13 / 2$.

Fig. 13. Leiosphaeridia sp.; pebble Mä-96-2H, prep. 3, N33/2. 


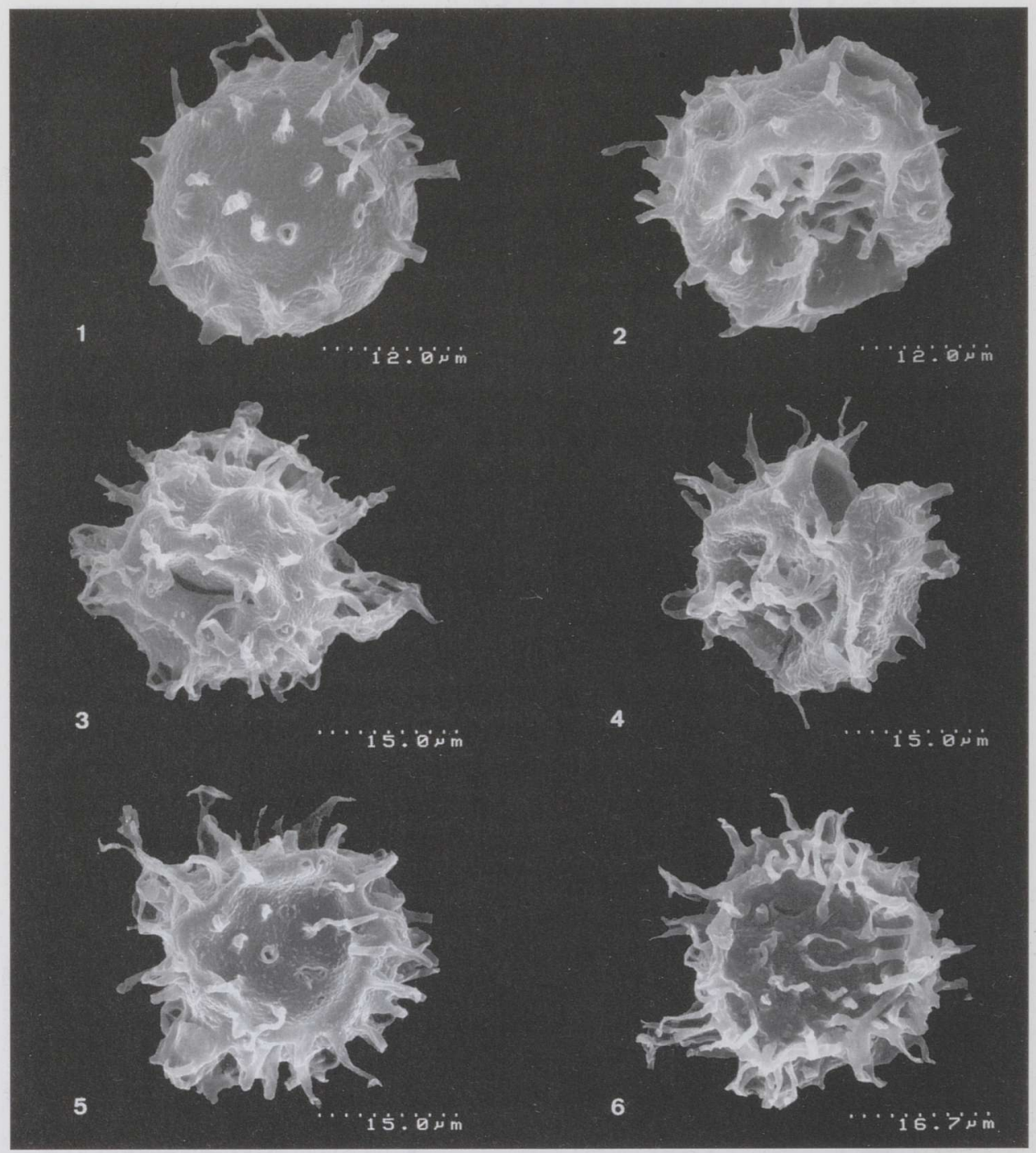

Figs. 1-6. Skiagia ciliosa (Volkova) Downie from pebble Mä-96-2C. 1, sample SCAN-96, I/A7. 2, sample SCAN-96, I/B5. 3, sample SCAN-96, I/B17. 4, sample SCAN-96, I/B11. 5, sample SCAN-96, I/B4. 6, sample SCAN-96, I/B10.

Figs. 1-8. Acritarchs from pebble Mä-96-2C.

$\rightarrow$

Fig. 1. Cymatiosphaera postii (Yankauskas); sample SCAN-96, I/B16.

Fig. 2. Dictyotidium sp.; sample SCAN-96, I/A4.

Fig. 3. Cymatiosphaera postii (Yankauskas); sample SCAN-96, I/B15.

Fig. 4. Acritarcha gen. et sp. indet. 2; sample SCAN-96, I/A2.

Figs. 5, 6. Asteridium tornatum (Volkova) Moczydłowska. 5, sample SCAN-96, I/A1. 6, sample SCAN-96, I/B6.

Figs. 7, 8. Globosphaeridium cerinum (Volkova) Moczydłowska. 7, sample SCAN-96, I/B1. 8, sample SCAN-96, I/A10. 
PLATE III

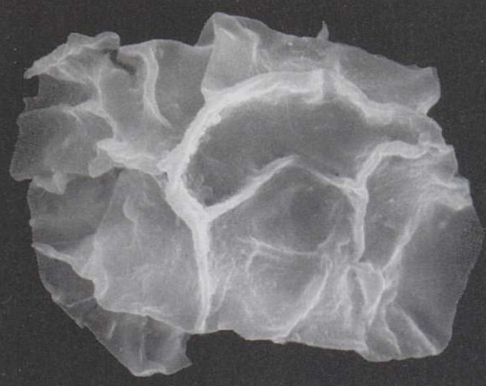

1
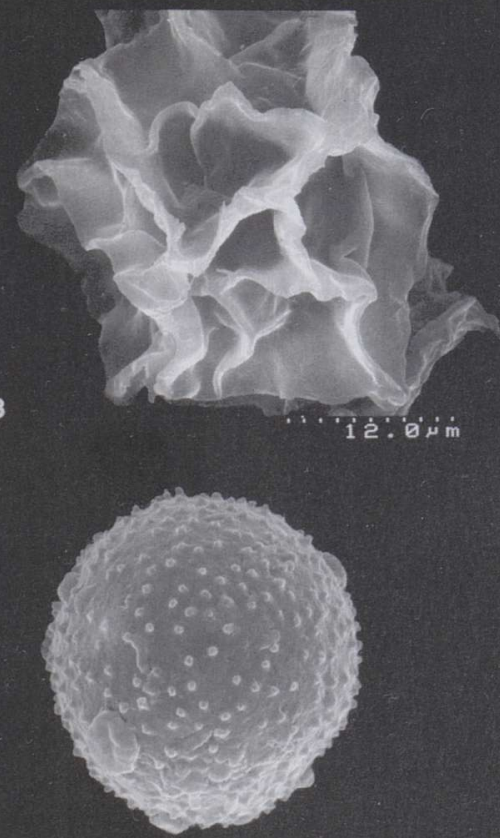

5

- iอ่:อั่́m

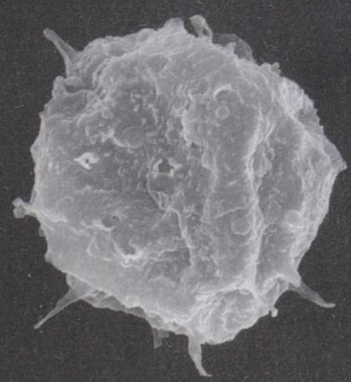

is:0ं

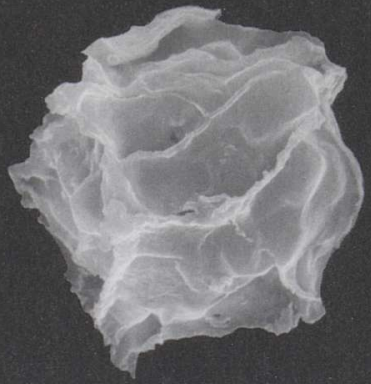

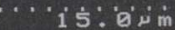

4
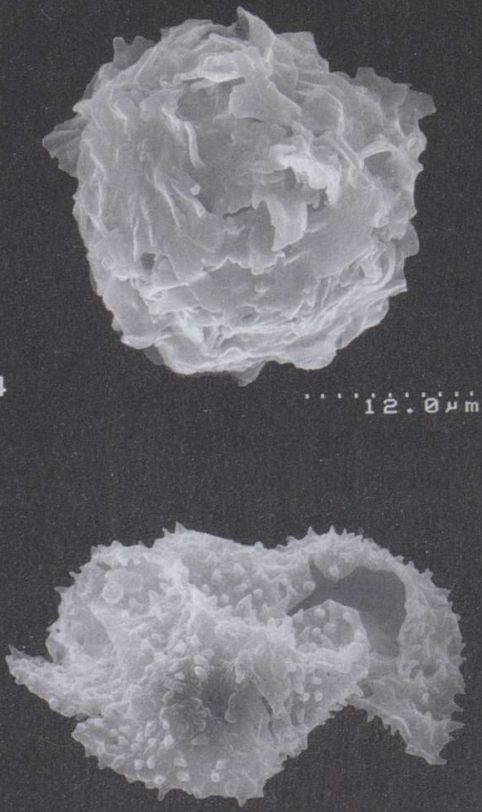

6 $15: 00 \%$ m

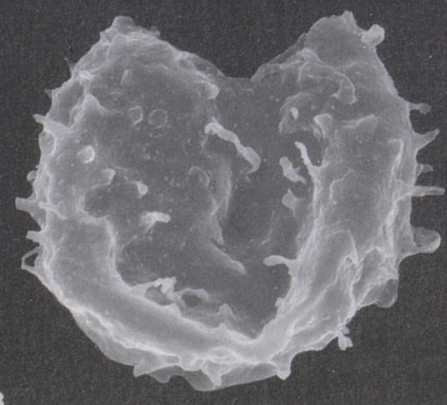

$16: 7 \mathrm{sin}$ 
Formation in western Estonia or from the Vaki Formation in middle and southern Estonia (Fig. 2). Pebble Mä-96-2G yielded a limited number of acritarchs, including Leiosphaeridia sp., represented by 15 specimens. Rare specimens of Asteridium lanatum, A. tornatum, and Lophosphaeridium dubium, typical of the Lower Cambrian deposits, were also identified. However, ?Celtiberium sp. (similar to the specimens occurring in pebble $\mathrm{Pa}-96-1 \mathrm{G}$ ), represented by two specimens is mostly known from the Middle Cambrian. As in case of the pebble from the Pakri Peninsula (Pa-96-1G), the options of the Middle Cambrian source rock and its distribution area remain intriguing.

\section{The basal conglomerate of the Kallavere Formation on the Pakri Peninsula}

According to the conodonts from the conglomerate matrix, the conglomerate at the base of the Kallavere Formation on the Pakri Peninsula is of Upper Cambrian age, not younger than the Cordylodus proavus Zone (Mens et al., 1996). In our pilot study of acritarchs from this conglomerate (Mens et al., 1997), we reported an acritarch assemblage from the matrix around a pebble that may be slightly older than the Acanthodiacrodium angustum acritarch Zone of Volkova (1990).

The eight pebbles selected for this study (Fig. 4) were composed of siltstone or sandstone, pyritized to a certain extent, usually having a pyritized rim. Pebble $\mathrm{Pa}-96-1 \mathrm{~F}$ did not yield microfossils, and $\mathrm{Pa}-96-1 \mathrm{D}$ contained only bacteriomorphs. Two pebbles, Pa-96-1A and Pa-96-1C, contained only long-range leiosphaeriid acritarchs, inconclusive for biostratigraphic purposes. In case of pebble Pa-96-1B, the acritarchs are likely from the fissure-filling matrix. The remaining three pebbles, Pa-96-1E, Pa-96-1G, and Pa-96-1H, contained diverse and rich assemblages, with the acritarch yield reaching 100 specimens per gram of rock. The assemblages from these samples allow us to interpret their possible source rocks. Pebble $\mathrm{Pa}-96-1 \mathrm{H}$ contained a limited number of small acanthomorphic acritarchs from the genera Asteridium and Heliosphaeridium and very rare specimens of Cymatiosphaera, Dictyotidium (Pl. I, figs. 8-10), Retisphaeridium, and Leiosphaeridia (Fig. 4). Heliosphaeridium coniferum occurs in the Skiagia ornata-Fimbriaglomerella membranacea acritarch Zone (Moczydłowska, 1991). The first Heliosphaeridium radzynicum appeared late in the Heliosphaeridium dissimilare-Skiagia ciliosa Zone which correlates with the Holmia kjerulfi trilobite Zone (Moczydłowska, 1991). The co-occurrence of $H$. radzynicum and $H$. coniferum is documented in the $S$. ornata-F. membranacea acritarch Zone. Due to the lack of zonal species, our conclusions are based on the above indirect evidence. The assemblage is of Lower Cambrian age, and the potential parent rocks of the pebble can be either the Irbe or Soela formations in western Estonia or the Vaki Formation in middle and southern Estonia (Fig. 2). Rather unexpectedly, pebble $\mathrm{Pa}-96-1 \mathrm{G}$ yielded an assemblage of tentative Middle Cambrian age. The 


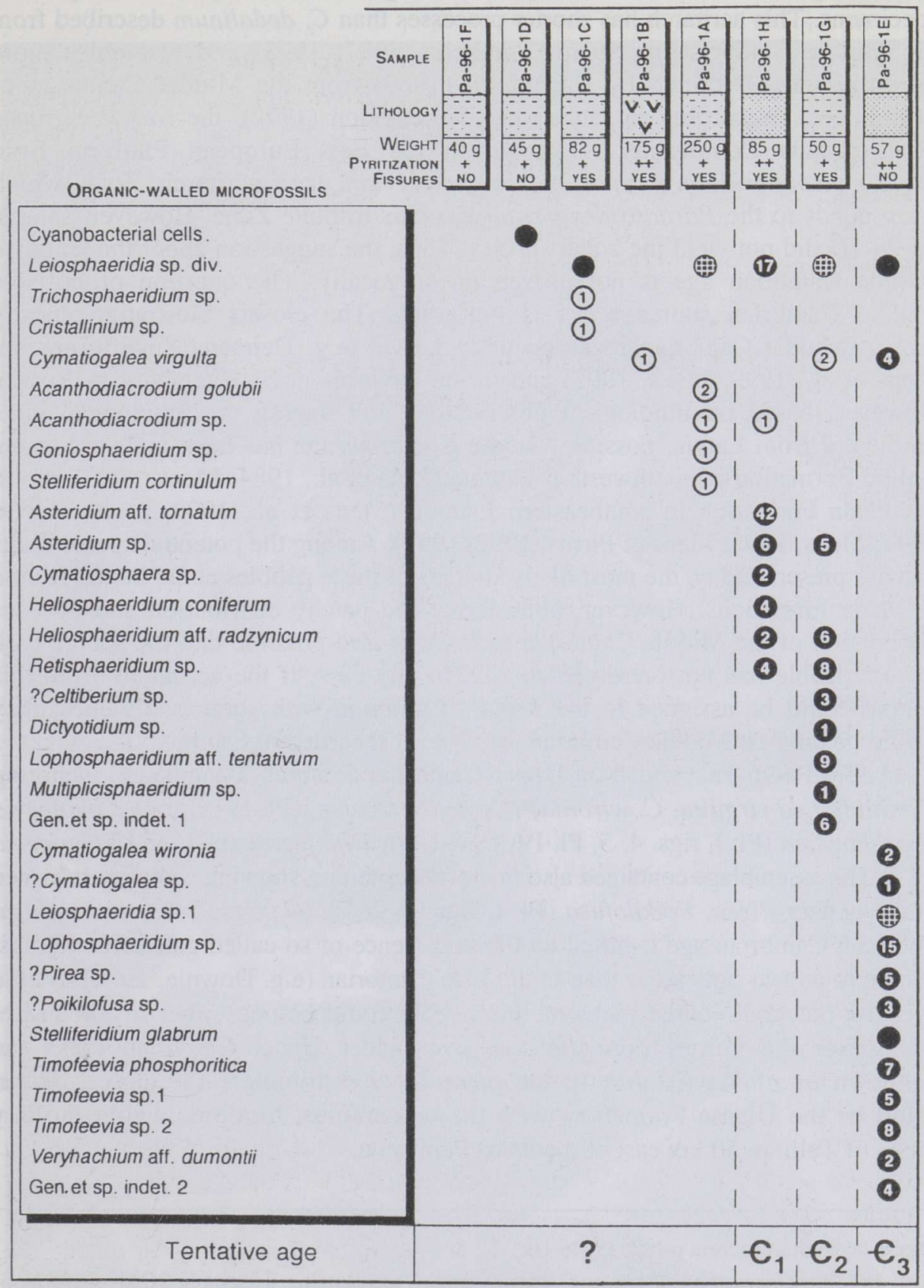

Fig. 4. Acritarch assemblages from the pebbles in the basal conglomerate of the Kallavere Formation in the Pakri Peninsula section. For legend see Fig. 3. 
form assigned to ?Celtiberium sp. (PI. I, figs. 6, 7) is represented by three specimens. This acritarch has shorter processes than $C$. dedalinum described from the Middle Cambrian of Spain (Fombella, 1977, 1978) and resembles more the specimens described by Hagenfeldt (1989) from the Middle Cambrian of Scandinavia. According to Jankauskas \& Lendzion (1992), the first occurrence of the genus Celtiberium is known in the East European Platform from the Comasphaeridium strigosum-Timofeevia lancarae acritarch Zone which corresponds to the Paradoxides paradoxissimus trilobite Zone. However, sample $\mathrm{Pa}-96-1 \mathrm{G}$ did not yield the zonal species. Thus, the suggestion about the tentative Middle Cambrian age is not proven unequivocally. The question of possible Middle Cambrian source rocks is intriguing. The closest biostratigraphically proven Middle Cambrian rocks occur in Latvia (e.g. Deimena Superformation; Mens et al., 1990; Mens, 1992) and in the environs of St Petersburg in Russia. However, based on lithological observations and tracing the lithological units northward from Latvia, possible Middle Cambrian age has been assigned to the Ruhnu Formation in southwestern Estonia (Kala et al., 1984; Mens, 1992) and to the Paala Formation in southeastern Estonia (Mens et al., 1990, p. 40; Pirrus, 1991; Mens, 1992; Mens \& Pirrus, 1992, 1997). Among the potential source rocks that are present today, the most likely sources of these pebbles could be the Ruhnu or Paala formations. However, considering the patchy distribution and obvious denudation of the Middle Cambrian rocks, it is also possible that the source rock of this pebble has not preserved in situ. In any case, if the acritarchs from this pebble could be assigned to the Middle Cambrian with some confidence, they would be the first Middle Cambrian fossils ever recorded in Estonia.

Pebble Pa-96-1E yielded an Upper Cambrian acritarch assemblage, including Cymatiogalea virgulta, C. wironia, ?Cymatiogalea sp. (Pl. IV, fig. 4), Timofeevia phosphoritica (Pl. I, figs. 4, 5; Pl. IV, figs. 1-3), Timofeevia sp. 1, and Timofeevia sp. 2. The assemblage contained also fusiform acritarchs, showing some resemblance to the genera Pirea, Poikilofusa (Pl. I, figs. 1, 2; Pl. IV, figs. 5-8), or Leiofusa. The Late Cambrian age is based on the occurrence of so-called galeate acritarchs, known to appear not earlier than in the Late Cambrian (e.g. Downie, 1984). By the age, the potential source rocks of this pebble could belong either to the Tsitre, Ülgase, or the Petseri Formation, or even older Upper Cambrian rocks yet unknown in situ in Estonia. In the present-day distribution, the closest option could be the Ülgase Formation, with the westernmost localities within the city limits of Tallinn, $50 \mathrm{~km}$ east of the Pakri Peninsula.

Figs. 1-8. Acritarchs from pebble Pa-96-1E.

Figs. 1-3. Timofeevia phosphoritica (Vanguestaine) Vanguestaine. 1, sample SCAN-96, III/A5. 2, sample SCAN-96, III/B2. 3, sample SCAN-96, II/B4.

Fig. 4. ?Cymatiogalea sp.; sample SCAN-96, III/A1.

Figs, 5, 6. ?Poikilofusa sp.; sample SCAN-96, III/B8.

Figs. 7, 8. ?Pirea sp.; sample SCAN-96, III/B6. 


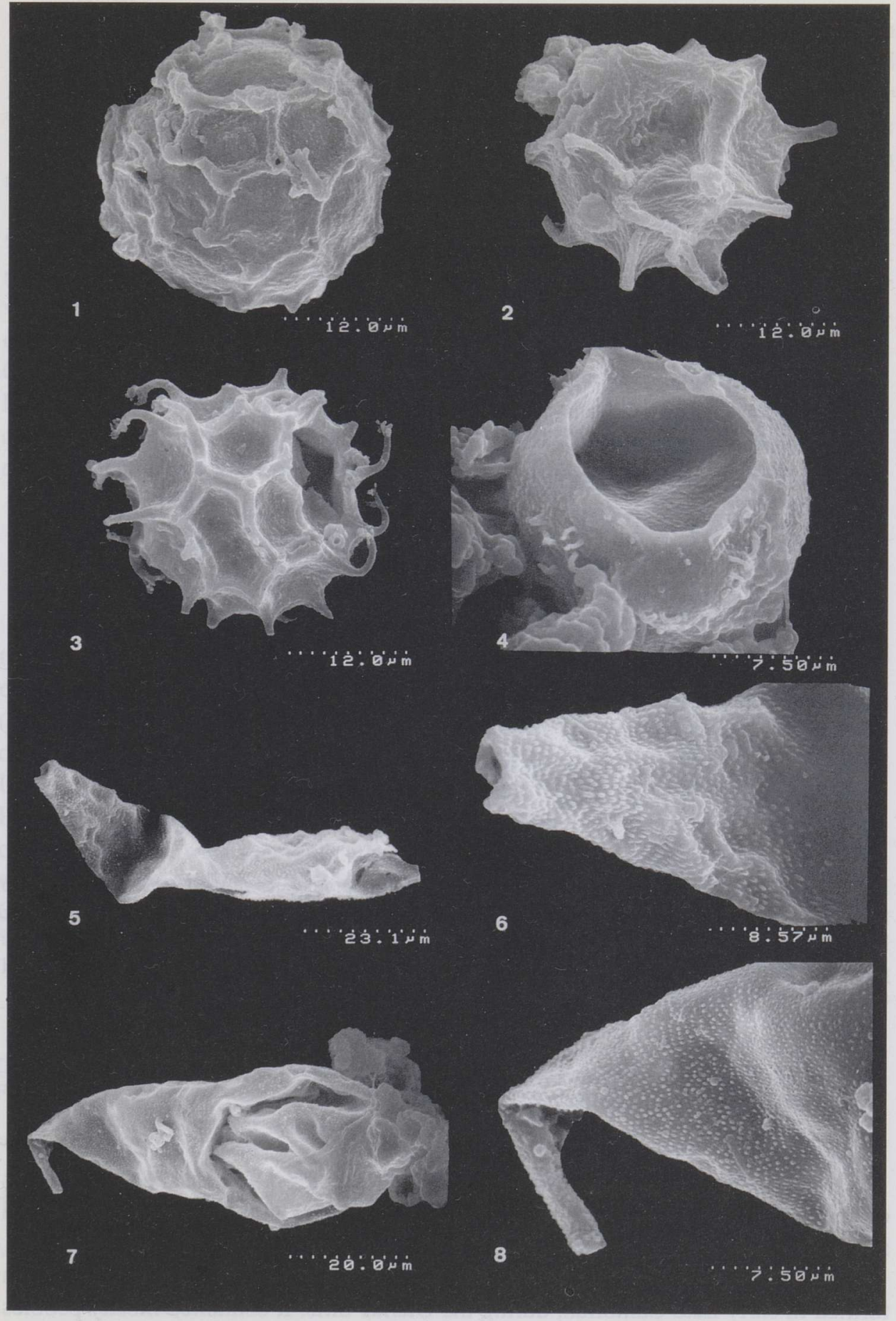




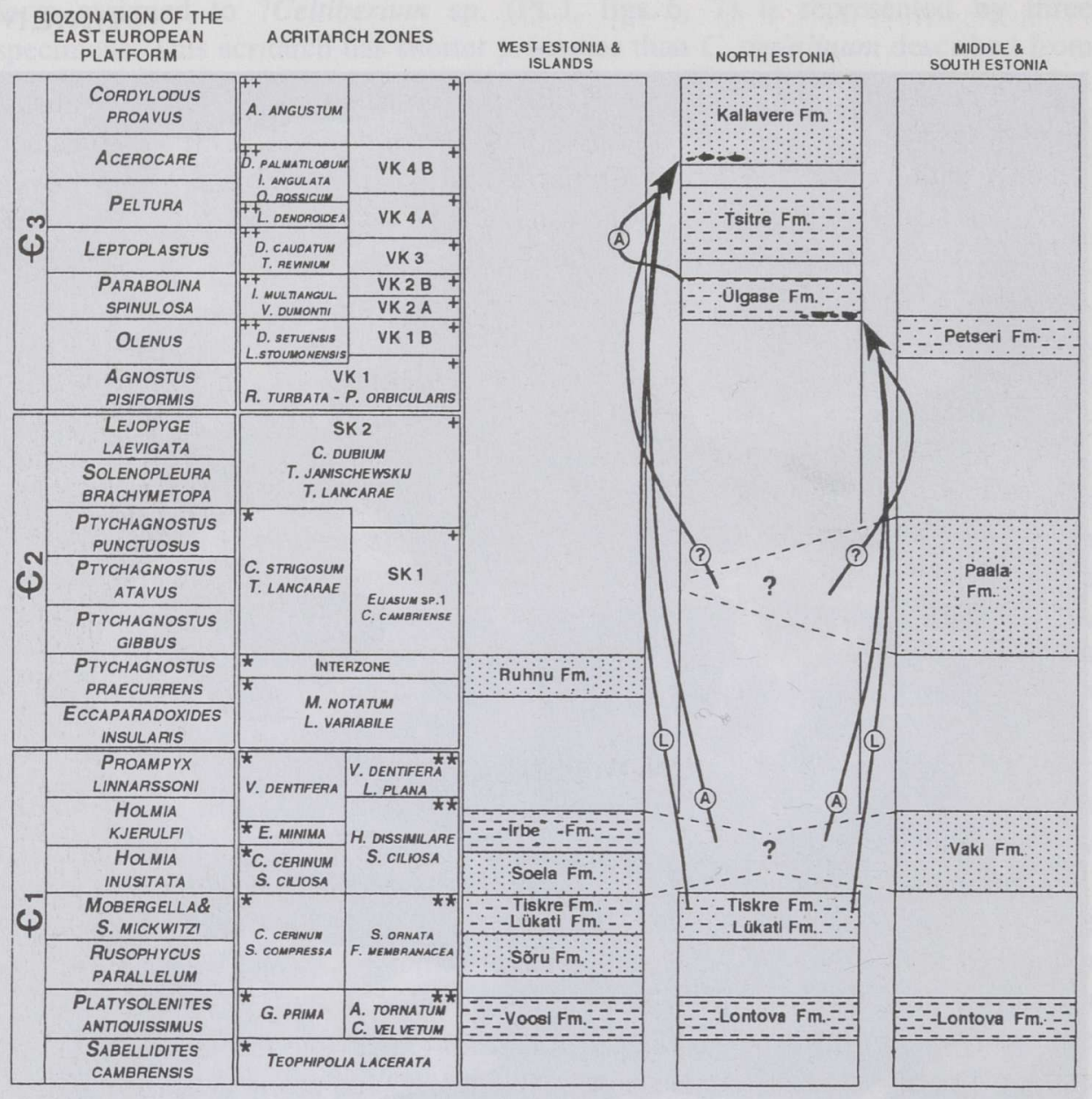

Fig. 5. Potential source rocks of the pebbles in the basal conglomerates of the Ülgase and Kallavere formations. Acritarch zones after Mens et al., 1993 (++), Volkova, 1990 (+), Jankauskas \& Lendzion, $1992\left(^{*}\right)$, and Moczydlowska, $\left.1991{ }^{* *}\right)$. The stratigraphic age of the source rocks is proven by acritarchs (A), disputable (?), or suggested by distinct lithologies (L). Lithological legend depicts the prevailing lithologies: arenaceous (dotted) or argillaceous (dashed) rocks.

\section{CONCLUSIONS}

Our hypotheses about the source rocks of the pebbles in the basal conglomerates of the Ülgase and Kallavere formations in the Mäekalda and Pakri Peninsula sections, respectively, are summarized in Fig. 5.

The basal conglomerate of the Ülgase Formation in the Mäekalda section formed in early Late Cambrian, during the Olenus time. It contained mostly pebbles 
originating from the Lower Cambrian source rocks, most likely from the Tiskre, Soela, or Vaki formations.

The basal conglomerate of the Kallavere Formation in the Pakri Peninsula section, formed slightly before or during the Cordylodus proavus time, contained pebbles with Lower and Upper Cambrian acritarch assemblages. The Lower Cambrian source rocks are likely the same as for the pebbles at the base of the Ülgase Formation. The Upper Cambrian source rocks originate most likely from the Ülgase or the Tsitre Formation.

Both conglomerates contained rare pebbles with an acritarch assemblage yielding ?Celtiberium sp. of tentative Middle Cambrian age. Possible Middle Cambrian source rocks may be associated with the Ruhnu Formation in western Estonia or with the Paala Formation in middle Estonia. Alternatively, the pebbles may originate from a missing, completely denudated and reworked part of the Middle Cambrian sequence. Because of the lack of biostratigraphic evidence for the Middle Cambrian age of the Ruhnu and Paala formations, and with only indirect evidence for the tentative Middle Cambrian age of the pebbles, all these options remain at the level of a work hypothesis for further research.

\section{ACKNOWLEDGEMENTS}

This study is a contribution to the research project "Tracing the hiatus in the Cambrian-Ordovician boundary interval in NW Estonia on the ground of overlying basal conglomerate" supported by the Estonian Science Foundation (grant No. 2189). We thank Ülo Kestlane, Institute of Geology, Tallinn, for cutting the samples from the pebbles. The Palynological Laboratory, Technical University of Berlin, is acknowledged for making available the facilities (to Ivo Paalits) for palynological sample preparation, light microscopy and SEM studies of the acritarchs, with special thanks to Jörg Nissen and Hanna Glowa for the help with photography. We are grateful to Dimitri Kaljo and Jaak Nõlvak, Institute of Geology, Tallinn, for critically reading and improving the manuscript.

\section{REFERENCES}

Downie, C. 1984. Acritarchs in British stratigraphy. Geol. Soc. London Spec. Rep., 17.

Fombella, M. A. 1977. Acritarcos de edad Cambrico Medio-inferior de la provincia de Léon, España. Rev. Esp. Micropaleontol., 9, 1, 115-124.

Fombella, M. A. 1978. Acritarcos de la Formacion Oville, Edad Cambrico, Medio-Tremadoc, Provincia de Léon, España. Palinologia, Numero extraordinario, 1, 245-261.

Hagenfeldt, S. 1989. Middle Cambrian acritarchs from the Baltic Depression and south-central Sweden, taxonomy and biostratigraphy. Stockholm Contrib. Geol., 41, 177-250.

Jankauskas, T. \& Lendzion, K. 1992. Lower and Middle Cambrian acritarch-based biozonation of the Baltic Syneclise and adjacent areas (East European Platform). Przeglad Geologiczny, 9, 519-525. 
Kala, E. A., Mens, K. A. \& Pirrus, E. 1984. On the stratigraphy of the Cambrian in West Estonia. In Stratigrafiya drevnepaleozoiskikh otlozhenij Pribaltiki (Männil, R. M. \& Mens, K. A., eds), pp. 18-35. Institut geologii, Akademiya nauk Éstonskoj SSR, Tallinn (in Russian).

Kaljo, D., Borovko, N., Heinsalu, H., Khazanovich, K., Mens, K., Popov, L., Sergeyeva, S., Sobolevskaya, R. \& Viira, V. 1986. The Cambrian-Ordovician boundary in the BalticLadoga clint area (north Estonia and Leningrad region, USSR). Proc. Acad. Sci. ESSR. Geol., 35, 3, 97-108.

Mens, K. 1992. Katalog stratotipov venda $i$ kembriya Pribaltiki. Institut geologii, AN Éstonii, Tallinn (in Russian).

Mens, K. \& Pirrus, E. 1987. Hiatuses in the East Baltic Vendian and Cambrian sections. Proc. Acad. Sci. ESSR. Geol., 36, 2, 49-57 (in Russian).

Mens, K. \& Pirrus, E. 1992. On the distribution of Middle Cambrian deposits in North Vooremaa, Estonia. Proc. Estonian Acad. Sci. Geol., 41, 1, 1-10 (in Russian).

Mens, K. \& Pirrus, E. 1997. Cambrian. In Geology and Mineral Resources of Estonia (Raukas, A. \& Teedumäe, A., eds.), pp. 39-51. Estonian Academy Publishers, Tallinn.

Mens, K., Viira, V., Paalits, I. \& Puura, I. 1989. Cambrian-Ordovician boundary beds at Mäekalda, Tallinn, North Estonia. Proc. Estonian Acad. Sci. Geol., 38, 3, 101-111.

Mens, K., Bergström, J. \& Lendzion, K. 1990. The Cambrian System on the East European Platform. Correlation chart and explanatory notes. IUGS Publ., 25.

Mens, K., Viira, V., Paalits, I. \& Puura, I. 1993. Upper Cambrian biostratigraphy of Estonia. Proc. Estonian Acad. Sci. Geol., 42, 4, 148-159.

Mens, K., Heinsalu, H., Jegonjan, K., Kurvits, T., Puura, I. \& Viira, V. 1996. CambrianOrdovician boundary beds in the Pakri Cape section, NW Estonia. Proc. Estonian Acad. Sci. Geol., 45, 1, 9-21.

Mens, K., Paalits, I. \& Puura, I. 1997. Upper Cambrian acritarchs from the basal conglomerate of the Kallavere Formation on the Pakri Peninsula, NW Estonia. Acta Universitatis Carolinae Geologica, 40, 531-543.

Moczydłowska, M. 1991. Acritarch biostratigraphy of the Lower Cambrian and the PrecambrianCambrian boundary in southeastern Poland. Fossils Strata, 29.

Müürisepp, K. 1958. Die Beschaffenheit der unteren Grenze der Packerort-Stufe von Packerort bis zum Sjäss-Fluss. ENSV TA Uurimused, 3, 55-79 (in Russian).

Nemliher, J. \& Puura, I. 1996. Upper Cambrian basal conglomerate of the Kallavere Formation on the Pakri Peninsula, NW Estonia. Proc. Estonian Acad. Sci. Geol., 45, 1, 1-8.

Paalits, I. 1992a. Upper Cambrian acritarchs from Petseri Formation (East European Platform). Acta Comment. Univ. Tartuensis, 956, 44-55.

Paalits, I. 1992b. Upper Cambrian acritarchs from boring core M-72 of North Estonia. Proc. Estonian Acad. Sci. Geol., 41, 1, 29-37.

Paalits, I. 1995. Acritarchs from the Cambrian-Ordovician boundary beds at Tõnismägi, Tallinn, North Estonia. Proc. Estonian Acad. Sci. Geol., 44, 2, 87-96.

Pirrus, E. 1991. The Middle Cambrian of Estonia. Proc. Estonian Acad. Sci. Geol., 40, 4, 141-151 (in Russian).

Popov, L. E., Khazanovich, K. K., Borovko, N. G., Sergeyeva, S. P. \& Sobolevskaya, R. F. 1989. The key sections and stratigraphy of the phosphate-bearing Obolus beds of the North-East of Russian Platform. AN SSSR, Mezhvedomstvennyi stratigraficheskij komitet SSSR, Trudy, 18 (in Russian).

Volkova, N. A. 1982. On the age of the Ülgase Member at the Cambrian-Ordovician boundary in Estonia. Sov. Geol., 9, 85-88 (in Russian).

Volkova, N. A. 1990. Acritarchs from the Middle and Upper Cambrian of the East European Platform. Nauka, Moscow (in Russian).

Volkova, N. A. \& Mens, K. 1988. Distribution of acritarchs in the Cambrian-Ordovician boundary beds of the Suhkrumägi section (North-Estonia). Proc. Acad. Sci. ESSR. Geol., 37, 3, 97-102 (in Russian). 


\title{
EESTI ÜLEMKAMBRIUMI BASAALKONGLOMERAATIDE VEERISTE BIOSTRATIGRAAFILINE ISELOOMUSTUS
}

Kaisa MENS, Ivo PAALITS ja Ivar PUURA

Kallavere ja Ülgase kihistu basaalkonglomeraadi veeriste akritarhide uurimisel Pakri poolsaare ja Mäekalda (Kadriorg) läbilõikes selgitati nende lähtekivimite stratigraafiline kuuluvus. Ülgase kihistu basaalkonglomeraadis valdavad alamkambriumi päritoluga veerised. Vähem on oletatavalt keskkambriumis moodustunud setenditest pärinevaid veeriseid. Kallavere kihistu basaalkonglomeraadis on lisaks nimetatuile leitud ka ülemkambriumi alumisest osast pärit veeriseid.

\section{БИОСТРАТИГРАФИЧЕСКАЯ ХАРАКТЕРИСТИКА ГАЛЕК ВЕРХНЕКЕМБРИЙСКИХ БАЗАЛЬНЫХ КОНГЛОМЕРАТОВ ЭСТОНИИ}

\author{
Кайса МЕНС, Иво ПААЛИТС и Ивар ПУУРА
}

Изучение акритарх из галек верхнекембрийских базальных конгломератов юлгазеской и каллавереской свит Эстонии позволило установить их стратиграфическую принадлежность к исходной породе. Гальки базального конгломерата юлгазеской свиты переотлагались в основном из нижнего кембрия. Численность галек, условно относимых к среднему кембрию, незначительна. В базальном конгломерате каллавереской свиты дополнительно к упомянутым встречаются гальки, унаследованные из более древних верхнекембрийских пород. 